\title{
The Quaternary record of eastern Svalbard - an overview
}

\author{
JON Y. LANDVIK, CHRISTIAN HJORT, JAN MANGERUD, PER MÖLLER and OTTO SALVIGSEN
}

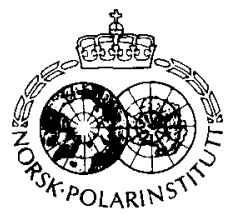

Landvik, J. Y., Hjort, C., Mangerud, J., Möller, P. \& Salvigsen, O. 1995: The Quaternary record of eastern Svalbard - an overview. Polar Research 14(2), 95-103.

The eastern part of the Svalbard archipelago and the adjacent areas of the Barents Sea were subject to extensive erosion during the Late Weichselian glaciation. Small remnants of older sediment successions have been preserved on Edgeøya, whereas a more complete succession on Kongsøya contains sediments from two different ice-free periods, both probably older than the Early Weichselian. Ice movement indicators in the region suggest that the Late Weichselian ice radiated from a centre east of Kong Karls Land. On Bjørnøya, on the edge of the Barents Shelf, the lack of raised shorelines or glacial striae from the east indicates that the western parts of the ice sheet were thin during the Late Weichselian. The deglaciation of Edgeøya and Barentsøya occurred ca 10,300 BP as a response to calving of the marine-based portion of the ice sheet. Atlantic water, which does not much influence the coasts of eastern Svalbard today, penetrated the northwestern Barents Sea shortly after the deglaciation. At that time, the coastal environment was characterised by extensive longshore sediment transport and deposition of spits at the mouths of shallow palaeo-fjords.

Jon Y. Landvik, The University Courses on Svalbard (UNIS), P.O. Box 156. N-9I70 Longyearbyen, Norway; Christian Hjort and Per Möller, Department of Quaternary Geology, Lund University, Sölvegatan 13, S-223 62 Lund, Sweden; Jan Mangerud, Department of Geology, University of Bergen, Allégt. 41, N5007 Bergen, Norway; Otto Salvigsen, Norwegian Polar Institute, P.O. Box 5072 Majorstua, N-0301 Oslo, Norway.

\section{Introduction}

The Quaternary geology of the Svalbard archipelago (Fig. 1) has been the subject of extensive research during the last three decades. The investigations have concentrated in particular on the largest island, Spitsbergen (Fig. 2), and models have been developed for the Late Quaternary glaciations (Boulton 1979; Miller 1982; Landvik et al. 1992a; Mangerud \& Svendsen 1992), glacioisostatic rebound (Schytt et al. 1968; Forman 1990; Forman et al. 1995) and the Holocene marine conditions of both Svalbard and the adjacent seas (Salvigsen et al. 1992). However, due to the more difficult accessibility, less progress has been made in understanding the Quaternary geology of the eastern islands of the archipelago such as Edgeøya, Barentsøya and Kong Karls Land (Fig. 2). These islands, however, are critical for the understanding of the geology of the northern Barents Sea, and their geological history is fundamental for the development of regional models.

As a result of both the PONAM programme (Polar North Atlantic Margins, Late Cenozoic Evolution) and hydrocarbon exploration in the Barents Sea, renewed interest has been expressed in the Quaternary geology of the sea floor and the surrounding land mass. Thus, the eastern islands of the Svalbard archipelago can now contribute towards an integrated understanding of the Quaternary development along a profile from the central Barents Sea to the continental shelf west of Svalbard. In this paper we summarise the main results obtained from the PONAM expeditions to Edgeøya, Barentsøya, Kongsøya and Bjørnøya, and use the new data to compare and modify the present models of the Quaternary history of Svalbard and the Barents Sea.

\section{The Late Quaternary record}

\section{The pre-Late Weichselian}

Sediments which record the Late Quaternary ice growth and decay have been preserved in several sections on Spitsbergen (Boulton 1979; Troitsky et al. 1979; Miller 1982; Miller et al. 1989; Landvik et al. 1992a; Mangerud \& Svendsen 1992; Mangerud et al. 1992) and an updated glaciation curve for the last interglacial/glacial cycle of Svalbard and the northern Barents Sea was recently suggested by Mangerud et al. (1996), based on correlation of the different sediment successions. 


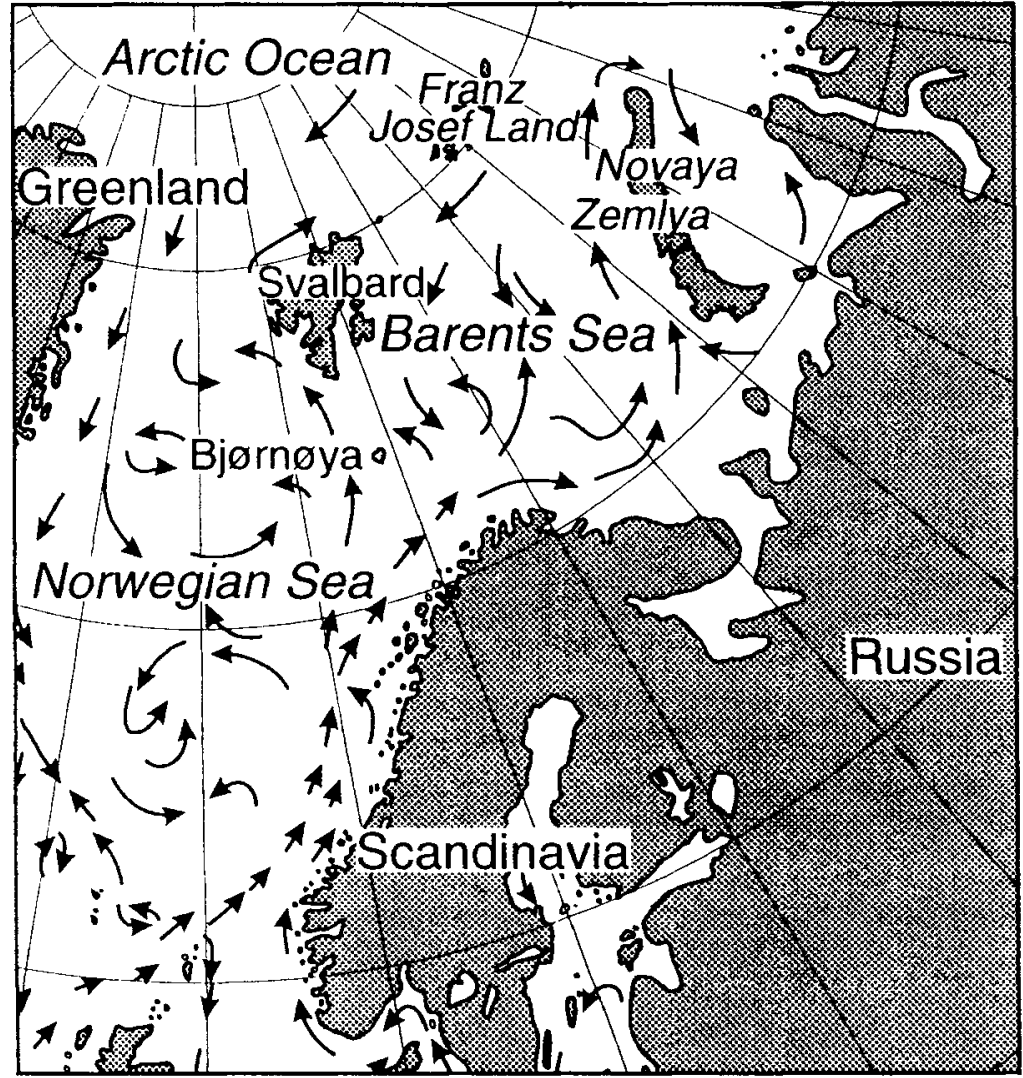

Fig. 1. Regional map showing the main areas discussed in the text. The present oceanic surface circulation is indicated.
These studies inferred from the Spitsbergen sites that the northern Barents Sea was covered by ice sheets during most of the Weichselian, except for two intervals at around $80 \mathrm{ka}$ and $30-50 \mathrm{ka}$. The Barents Sea part of this reconstruction is based on the assumption that high relative sea levels during ice free periods on Spitsbergen were caused by glacial loading in the northern Barents Sea.

During the PONAM expeditions, pre-Late Weichselian sediments were found on Edgeøya and on Kong Karls Land (Fig. 2). On northeastern Edgeøya. ice-free conditions are reflected by shell fragments embedded in beach sediments (Bondevik et al. 1995). The fragments yield infinite radiocarbon ages, and mean amino acid ratios (alle/Ile total) of $0.082 \pm 0.019(n=6)$. These ratios are similar to those from the oldest icefree period on Kongsøya (Ingólfsson et al. 1995). which are postulated to be of pre-Eemian age.

In Visdalen on western Edgeøya (Fig. 2), coarse-grained fan delta sediments were deposited along the northern valley slope at a time when the seal level was $>57 \mathrm{~m}$ above the present, and these were later covered by subglacial till (Möller et al. 1995). Sub-till sediments have also been reported from the adjacent Rosenbergdalen by Boulton (1990). Unfortunately, neither of these latter units could be dated.

The islands of Kong Karls Land (Fig. 2) hold a key position with regard to understanding the last interglacial/glacial cycle of the northern Barents Sea. Shells from Svenskøya have been dated to $40,000 \mathrm{BP}$ and older, and four driftwood logs from Kongsøya were more than 40.000 years old (Salvigsen 1981). One whalebone from eastern Kongsøya was dated to $33,600 \pm 970$ which was considered to be a minimum age by Salvigsen (1981). From northwestern Kongsøya, Ingólfsson et al. (1995) report sediment successions from two ice-free periods older than the Late Weichselian. Biostratigraphical studies suggest that the climate then was similar to or slightly warmer than the present (Ingólfsson et al. 1995). 


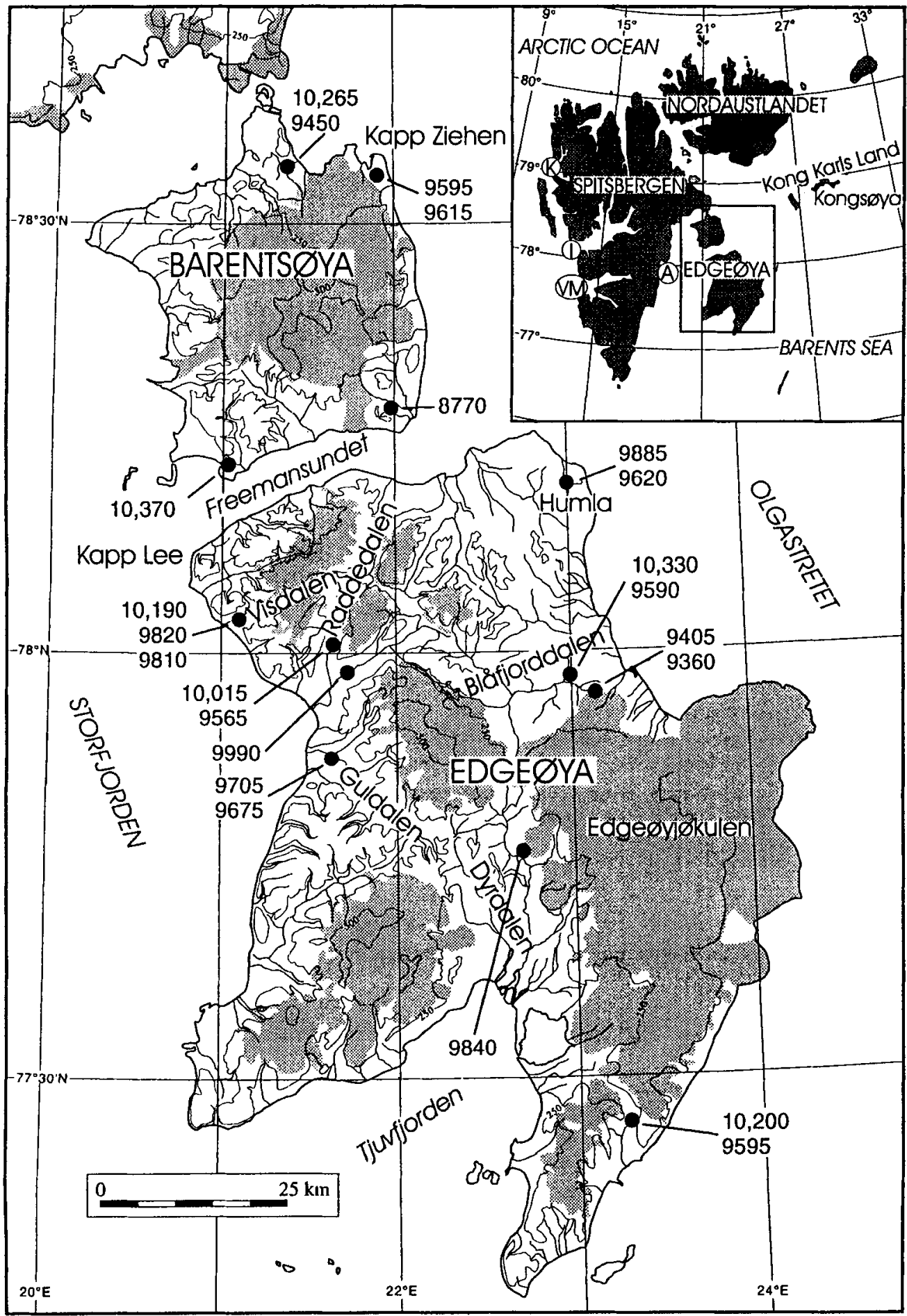

Fig. 2. Deglaciation dates from Edgeøya and Barentsøya. The two oldest dates have been listed from most of the study areas. Details are given in Table 1. The insert map also shows the location of Kongsfjorden (K), Isfjorden (I), Van Mijenfjorden (VM) and Agardhbukta (A). The glaciers on Edgeøya and Barentsøya are shaded. 
The older period is characterised by amino acid ratios (alle/Ile total) of $0.083 \pm 0.009$. and comparison with the amino acid ratios in the Eemian deposits at Kapp Ekholm (Mangerud \& Svendsen 1992) and luminescence dates. both support a preEemian age. The younger period, with amino acid ratios of $0.043 \pm 0.068$. is interpreted to be of either Early Weichselian or Eemian age (Ingólfsson et al. 1995).

Several scenarios for the progression of the last interglacial/glacial cycle of Svalbard and the northern Barents Sea have been suggested (Lindner et al. 1984; Larsen et al. 1991; Landvik et al. 1992a: Mangerud \& Svendsen 1992; Mangerud et al. 1996). Through time, these models have evolved a better foundation for reconstructing the area of the Barents Sea proper. Previous models (Larsen et al. 1991; Mangerud \& Svendsen 1992) suggested almost contemporaneous glacials and interstadials over Spitsbergen and the Barents Sea, whereas the later ones (Landvik et al. 1992a: Mangerud et al. 1996) suggest a long period of ice cover over the sea to the east of the Svalbard islands during the Early Weichselian. If the younger ice-free period on Kongsøya (Ingólfsson et al. 1995) is of an Early Weichselian age, we assumed that the whole Barents Sea must have been deglaciated. However, the time control so far is too rough to justify any revision of the latest models (Mangerud et al. 1996) for the last interglacial/glacial cycle of the Svalbard/Barents Sea region.

\section{The dynamics of the Late Weichselian ice sheet}

The extent of the ice sheet over Svalbard and the Barents Sea during the Late Weichselian has been the subject for debate for three decades (e.g. Schytt et al. 1968: Boulton 1979: Salvigsen 1981: Mangerud et al. 1992; Elverhøi et al. 1993). Based on the post glacial uplift pattern (Salvigsen 1981: Forman 1990), and the distribution of sea floor sediments. moraine ridges, and subglacially formed flutes (Elverhøi et al. 1993), there is a consensus today that the ice sheet covered at least the northern Barents Sea. For a short period. outlet glaciers advanced to the continental shelf west of Spitsbergen (Mangerud et al. 1992: Svendsen et al. 1992) and to the western Barents Sea shelf (Elverhoi et al. 1993). Recent models of ice sheet extent based on uplift data also suggest that the ice sheet extended to the shelf edge to the west and north of Svalbard (Lambeck 1995, 1996).
However, less is known about the exact timing and dynamics of the ice sheet.

The pattern of glacioisostatic rebound shows a centre of maximum uplift in the northern part of the Barents Sea (Schytt et al. 1968; Forman 1990). Bondevik et al. (1995) present detailed relative sealevel curves from Edgeøya and Barentsøya, and their revised isobase map for $10,000{ }^{14} \mathrm{C}$ years BP suggest a centre of uplift southeast of Kong Karls Land (Fig. 2). This compares with the isostatic models of Lambeck $(1995,1996)$ who also suggested that the ice sheet had its maximum ice thickness southeast of Kongsøya. Glaciological modelling of the ice sheet (Siegert \& Dowdeswell 1995 ) suggests a similar location for the maximum ice thickness. Based on reconstructions of ice flow directions, it has been suggested that the Svalbard and Barents Sea Ice Sheet consisted of several confluent ice domes and not only one single ice dome centered over the Barents Sea (Landvik \& Salvigsen 1985; Mangerud et al. 1992). However, this ice flow pattern may represent only phases of growth. or decay, of the ice sheet.

In the peripheral region of the former ice sheet, ice streams have been shown to drain along the Bjørnøya and Storfjorden troughs on the Barents Shelf (Elverhøi et al. 1993), and along Van Mijenfjorden and Isfjorden on Spitsbergen (Mangerud et al. 1992). Different sets of ice movement indicators (see review by Salvigsen et al. 1995) show phases when ice flow radiated from a centre east of Svalbard. Evidence for an ice sheet centred east of Kong Karls Land is also found on Kongsoya. where the sediments from the younger icefree period were deformed by a topographically independent glacier moving from the northeast (Ingólfsson et al. 1995). Even if these sediments are of an Early Weichselian age. we assume that such an ice movement must be attributed to the large Late Weichselian ice sheet.

On a larger scale, there is a systematic variation in the sediment distribution on the Barents Sea floor that fits the theoretical zonation of glacial erosion and deposition under an ice sheet as proposed by Sugden $(1977,1978)$. The shallow banks north of $74^{\circ}$, where bedrock is exposed over ca $50 \%$ of the area and sediment thickness is $<25 \mathrm{~m}$ (Solheim \& Kristoffersen 1984), can be ascribed to a zone of erosion. This contrasts with the zone of deposition to the southwest, where large sedimentary wedges increase in thickness towards the shelf margin, e.g. in the Bjørnøyrenna and Storfjordrenna troughs (Solheim \& 
Kristoffersen 1984; Vorren et al. 1990). Also the distribution of pre-Late Weichselian sediments on the Svalbard islands fits such a model. As reported here. Edgeøya and Barentsøya were subjected to extensive glacial erosion during the last glaciation, whereas most sediment accumulations of pre-Late Weichselian age are found on western Spitsbergen (Landvik \& Salvigsen 1985; Miller et al. 1989; Lønne \& Mangerud 1991; Landvik et al. 1992a; Mangerud \& Svendsen 1992). Several of these accumulations are in glacially-shaped fjord and valley basins or on the strandflat, and show that the Late Weichselian glacial erosion was probably less important in forming the glacial topography of western Spitsbergen.

\section{The Late Weichselian deglaciation}

The western margin of the Barents Ice Sheet reached the shelf break to the west during the Late Weichselian (Elverhøi et al. 1993; Mangerud et al. 1992), and the glacier must also have surrounded or covered Bjørnøya on the southwestern margin of Spitsbergenbanken. As indicated by many radiocarbon dates, the ice sheet started to recede from the outer coast of Spitsbergen at 13,000 BP (Forman 1990; Mangerud et al. 1992), whereas the central fjord region first became ice free ca $10,000 \mathrm{BP}$ (Mangerud et al. 1992). From the eastern part of the archipelago, the timing of the deglaciation had before the PONAM expeditions been based on only a few dates from Edgeøya and Barentsøya (Knape 1971; Nagy 1984; Forman 1990) and from Kongsøya (Salvigsen 1981). There were no satisfactory dates for the deglaciation of Bjørnøya until the studies of Wohlfarth et al. (1995).

Dating of the local deglaciation has been an aim of the PONAM studies, and a regionally welldistributed set of new dates from Edgeøya and Barentsøya is now available (Table 1, Fig. 2). These indicate a contemporaneous deglaciation at around $10,300 \mathrm{BP}$ along both the eastern and western coasts of the islands. However, dating of the oldest part of the sea level curves from the area (Bondevik et al. 1995), indicates that the deglaciation occurred ca 500 radiocarbon years later. The deglaciation probably progressed by rapid calving in both Storfjorden and Olgastretet (Fig. 2), and remnants of the glacier remained in the interior of Spitsbergen (Mangerud et al. 1992) and Edgeøya (Landvik et al. 1992b; Möller et al. 1995). We assume that the rapid emergence between 10,000 and $9000 \mathrm{BP}$. (Salvigsen 1981; Bondevik et al. 1995) is as a response to a major unloading just prior to $10,000 \mathrm{BP}$. The correspondence in time between the deglaciation dates of ca 10,000 BP for both Agardhbukta (Fig. 2) on the western side of Storfjorden (Salvigsen \& Mangerud 1991) and on Kongsøya (Salvigsen 1981) also suggests that the marine part of the ice sheet vanished due to rapid calving. At this time, the nature of the ice flow across high areas thus changed from being regionally governed by the configuration of the Barents Ice Sheet, to being more locally affected by the topography beneath the last ice remnants on the islands. On Bjørnøya (Fig. 1), glacial striae reflect only a local ice cap centred on the southern and middle part of the island (Salvigsen \& Slettemark 1995). The ice cap may also have been a remnant of the ice sheet, formed by rapid withdrawal of the western margin of the Barents Ice Sheet. Basal dates from lake sediments on the island show that most of the local glaciers had vanished before $9800 \mathrm{BP}$ (Wohlfarth et al. 1995).

\section{The Holocene}

The sediment records of Edgeøya and Barentsøya show that the physical environment at the Weichselian/Holocene transition was different from today. The large transverse ridges found at the mouths of several valleys were interpreted by Büdel (1968) to have been formed by longshore currents. They were later reinterpreted by Nagy (1984) as ice contact deltas, and taken as evidence for a halt in the deglaciation, called the "Visdalen event". New investigations of the sediment successions in Visdalen on Edgeøya (Fig. 2) (Möller et al. 1995) support Büdel's view, and show that thick piles of sediments were deposited as fan deltas which also fed longshore currents, depositing large ridge-formed spits at the mouths of inundated valleys between 10,000 and $9000 \mathrm{BP}$. The elevations of other similar ridges at the mouths of shallow paleo-fjords on Edgeøya and Barentsøya, suggest that these are of the same age as the one in Visdalen.

The formation of large spits (Moller et al. 1995) during a period of rapid regression (Bondevik et al. 1995), suggests that the longshore sediment transport during the Preboreal was considerably greater than today. In the situation immediately following the deglaciation, we assume that uncon- 


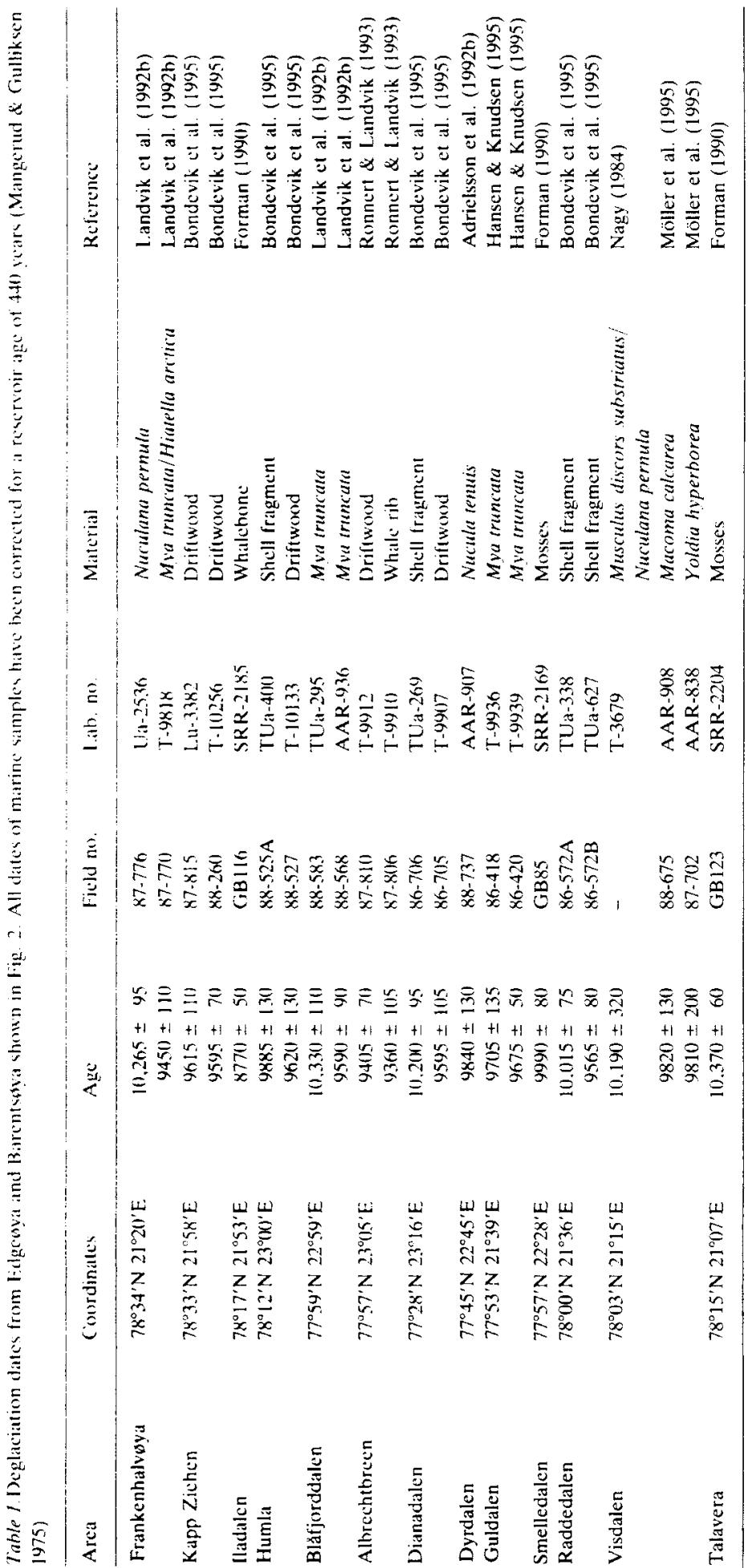


solidated glacial sediments deposited on unstable slopes were the most important source for the sediments deposited in the alluvial fans and fan deltas. The latter process may have been enhanced by an early Holocene hydrographic regime which was different from the present. The Svalbard waters experienced a stronger influx of Atlantic water during the early and middle Holocene as reflected by the influx of thermophilous molluscs already around $9500 \mathrm{BP}$ (Salvigsen et al. 1992). However, a detailed Preboreal climatic record based on foraminifera from raised glacimarine deposits at eastern Edgeøya suggests that the steady amelioration of the marine conditions was interrupted by a short cooling between 9600 and 9400 BP (Hansen \& Knudsen 1995). From findings of subfossil Mytilus edulis, a minjmum age of $8800 \mathrm{BP}$ was obtained for the first major influx of Atlantic water reaching Edgeøya (Hjort et al. 1995). This shows that the circulation in the northwestern part of the Barents Sea was different during the early Holocene, and it possibly may also have influenced the strength and pattern of the near-shore currents in the area.

At the same time, during the Preboral, the glaciers on Edgeøya receded beyond their present limits (Ronnert \& Landvik 1993) and the modern flora of the area was established (Bennike \& Hedenäs 1995). Most glacier margins in the area are today characterised by the retreat from young moraines formed by stacking of sheets of sediments during the Little Ice Age (Adrielsson et al. 1992; Ronnert \& Landvik 1993; Dowdeswell \& Bamber 1995).

\section{Conclusions}

The collaborative efforts during the PONAM expeditions to eastern Svalbard and Bjørnøya resulted in a new understanding of the geologica! development of this part of the Svalbard archipelago and the Barents Sea. The main results are summarised below.

1. Glacial erosion during the Late Weichselian removed most of the older sediments from the eastern parts of the Svalbard archipelago and adjacent parts of the Barents Sea. The erosion in this region was more extensive than on the western coast of Spitsbergen, where several older sediment successions have been preserved.

2. Deposits from two pre-Late Weichselian periods, with climates similar to or slightly warmer than the present on Kong Karls Land, show periods when the Barents Sea was completely deglaciated.

3 . Both the improved isobase reconstructions and isostatic modelling suggest that the Late Weichselian ice sheet had its maximum thickness southeast of Kong Karls Land.

4. Detailed relative sea level curves from Edgeøya and Barentsøya show that the glacioisostatic uplift $10,000-9000 \mathrm{BP}$ was rapid, responding to a major unloading just prior to $10,000 \mathrm{BP}$.

5. During the last deglaciation, the marinebased part of the ice sheet over eastern Svalbard underwent rapid calving, and most of the glacier fronts receded beyond the present day coasts of Edgeøya and Barentsøya before 10,300 BP.

6. The coastal environment immediately after the deglaciation was characterised by extensive longshore sediment transport. Large spit ridges were formed at the mouths of several valleys.

7. Subfossil Mytilus edulis indicate a major influx of Atlantic water into the northwestern Barents Sea between ca 8800 and 5000 BP.

Acknowledgements. - This paper is mainly the result of the expeditions within the PONAM (Polar North Atlantic Margins. Late Cenozoic Evolution) programme in 1991 and 1993. Fund. ing for the fieldwork was provided by the research councils in Denmark, Norway, Sweden and the U.K., as well as by the participants own institutions. The Norwegian group also received financiai support from Norsk Hydro, Saga Petroleum. Statoil and the Norwegian Petroleum Directorate, and the Swedish group from the Polar Research Secretariat. Helicopter transport in the field was made possible by a grant from the European Commission to the European Science Foundation. The Norwegian Polar Institute provided logistic support, and the use of $R / V$ LANCE during initial reconnaissance work and for transport to and from eastern Svalbard. Norwegian Polar Institute expedition leaders T. Siggerud (1991) and J. Haugland (1993) were most helpful to the two PONAM expeditions. In 1991 , B. Torgerhagen (pilot) and K. Nilsen (engineer) skillfully operated the helicopter from a base camp at Kapp Lec at Edgeøya. H. Eggenfellnex assisted in base operations. The Norwegian Coast Guard transported two field parties to Bjørnøya in 1993. All operations in eastern Svalbard were made possible through kind permissions from the Governor on Svalbard, who also assisted with helicopter transport from Kongsøya in 1993. To all these persons and institutions we offer our sincere thanks. Finally, all participants in the PONAM project are thanked for the open communication, and all the lively discussions that have contributed to the results we sec today.

\section{References}

Adrielsson, L.. Johansson, K. \& Hjort, C. 1992: Deglaciation and Holocene stratigraphy in a Little Ice Age composite- 
moraine in front of Seidbreen. Edgeoya. eastern Svalbard. Lundqua Rep. 35. 153-160

Bennike. O. \& Hedenäs. L. 1995: Early Holocene land floras and faunas from Edgeova. castern Swalbard. Polar Res. $1+12 \%$. 205-214.

Bondevik. S. Mangerud. J. Ronnert. L. \& Salvigsen. O. 1995 : Postglacial sea level history of Edgeoya and Barentsoya. eastern Sralbard. Polar Research 14121. 153-180.

Boution. G. S. 1979: Glucial history of the Spitsbergen archipelago and the problem of a Burents Shelf ice sheet. Boreas 8. $31-5$ ?

Boulton G. S. 1990: Sedimentary and sea level changes during glacial orcles and their control on glacimarine facies architecture. Pp. 15-52 in Dowdeswell. J. A \& Scourse. J. D. (cds.): Cilacimarine enciromments: Processes and sediments. Geol. Soc Spec. Puhl 53.

Büdel. J 1968: Dic junge Landhebung Spitzhergens im L'mkreis des Frecman-Sundes und der Olga-Strasse. Wuirsb. Geogr. Arb. $221.1-21$.

Doudeswill. J. A. \& Bamber. J. L. 1995: On the glaciology of Edgedya and Barentsoya. Sialbard. Polar Res. 14(2). 105122

Elverhoi. A. Fjeddskatr. W.. Solheim. A.. Nyland Berg. M. \& Ruwurm. 1. 1993: The Barents Sea Ice Sheet - A model of its grow th and decay during the last ice maximum. Qwat. Sei Rere, 12. 863-873.

Forman S 1941: Post-glicial relative sea-level history of northwestern Spitsbergen. Svalbard. Geol. Soc. Am. Bull. 102. $15811-15911$.

Forman. S.. Lubinski. D. Miller. G. H. Snyder . J. Matishov. Ci. Korsun. S \& Mislivets. V. 1995: Postglacial emergence and distribution of late Weichelian ice-sheet loads in the northern Barents and Kara seas. Russia. Geol. 23. 113-116.

Hanses. A. \$ Kntden. K. L. 1995: Kecent foraminiferal distribution in Frecmansundet and early Holocene stra. tigraphy on Edgeoya. Svalbard. Polar Res. 1412). 215-238.

Hjort. C.. Mangerud. J.. Adriclsson. L.. Bondevik. S. Landvik, J. Y. \& Salvigsen. O. 1995: Radiocarbon dated common mussels. Myrilus edulis from eastern Svalbard - and the Holocene marine dimatic optimum. Polar Res. 1412). $239-2+3$

Ingolfsson. O. Rögnvaldsson. F. Bergsten. H. Hedenäs, L.. Lemdahi. G. L.. Lirio. J. M. \& Sejrup. H. P. 1995: Late Quaternary glacial and environmental history of Kongsoya. Svalbard. Polar Research 1+12), 123-139.

Knape P. 1971: C-1 $\$$ dateringar at höjda strandlinjer. synkrona pimpstensnivaer och iakttagelser av högta kustlinjen pa Svalbard. Cnpublished fil. dr. thesis. Lnisersity of Stockholm. 1-142.

Lambeck. k. 1995: Constraints on the Latc Weichselian ice shect over the Barents Sea from observations of rased shorelines. Quat. Sci. Ret. 1t. 1-16.

Lambeck, K. 1996: Limits on the areal extent of the Barents Sea Ice Sheet in Late Wcichselian time. Global Planetary Change 12 (in press).

Landvik. J. Y. \& Salvigsen. O. 1985: Glaciation development and interstadial sea-lewed on central Spitsbergen. Svalbard Polar Res. 3n.. 1-10.

Landrik. J. Y.. Bolstad, M. L.ycke, A. K.. Mangerud, J. \& Sejrup. H. P. l942a: Weichselian stratigraphy and palaeo. environments at Bellsund. western Svalbard. Boreas 21.33.5$35 n$.

Landrik. J. Y. Itansen. A.. Kelly. M. Salvigsen, O. Slettemark. O. \& Stubdrup. O. P. 1992b: The last deglaciation and glacimarine/marine sedimentation on Barentsøya and Edgeoya, eastern Svalbard. Lundqua Rep. 35. 61-83.

Larsen, E., Sejrup, H. P.. Olsen, L. \& Miller, G. H. 1991: Late Quaternary land -- sea interactions: Fcnnoscandia and Svalbard - the nordic seas. Quat. Int. 10-12, 151-159.

Lindner. L.. Marks, L. \& Pekala, K. 1984: Late Quaternary glacial episodes in the Hornsund region of Spitsbergen. Boreas 13. 35-47.

Lonne. I. \& Mangerud. J. 1991: An Early or Middle Weichselian sequence of proglacial, shallow marine sediments on western Svalbard. Boreas 20, 85-104.

Mangerud. J. \& Gulliksen, S. 1975: Apparent radiocarhon ages of recent marine shells from Norway, Spitsbergen, and Arctic Canada. Quat. Res. 5, 263-273.

Mangerud. J. \& Svendsen. J. 1. 1992: The last interglacialglacial period on Spitshergen. Svalhard. Quat. Sci. Reo. 11, $633-664$

Mangerud. J.. Bolstad. M. . Elgersmá. A.. Helliksen. D. . Landvik. J. Y. Lonne. I.. Lycke. A. K.. Salvigsen, O., Sandahl, T. \& Siendsen. J. I. 1992: The last glacial maximum on Spitsbergen. Svalbard. Quat. Res. 38, 1-31.

Mangerud. J. Jansen. E. \& Landvik. J. Y. 1996: Late Cenozoic history of the Scandinavian - and Barents Sea ice shects. Global Planetary Change. 12 (in press).

Miller. G. H. 1982: Quaternary depositional episodes, western Spitsbergen. Norway: aminostratigraphy and glacial history. Arct. Alp. Res. 14, 321-340.

Miller. G. H.. Sejrup. H. P. Lehman. S. J. \& Forman, S. L. 1989: Glacial history and marine environmental change during the last interglacial-glacial cyclc, western Spitsbergen. Svalbard. Boreas 18,273-296.

Moller. P. Stubdrup. O. P. \& Kronborg. C. 1995: Late Weichselian to carly Holocene sedimentation in a stecp fjord/ valley setting. Visdalen. Edgeøya, eastern Svalbard: glacial deposits. alluvial/colluvial-fan deltas and spit-platforms. Polar Res. 14(2). 181-203.

Nagy. J. 1984: Qutemary glaciomarine deposits and foraminifera from Edgenya, Svalbard. Boreas 13, 319-332.

Ronnert. L. \& Landvik. J. Y. 1993: Holocene glacial advances and moraine formation at Albrechtbreen, Edgeøya, Svalbard. Polar Res. 12, 57-63.

Salvigsen. O. 1981: Radiocarbon dated raised beaches in Kong Karls Land. Svalbard. and their consequences for the glacial history of the Barents Sea. Georgr. Ann. 63A, 283-291.

Salvigsen. O. \& Mangerud. J. 1991: Holocene shoreline displacement at Agardhbukta. Spitsbergen. Svalbard. Polar Res. 9. $1-7$.

Salvigsen. O. Forman. S. \& Miller. G. H. 1992: Thermophilous molluses on Svalbard during the Holocenc and their paleoclimatic implications. Polar Res. 11. 11-10.

Salvigsen. O. \& Slettemark, Ø. 1995: Past glaciation and sea levels on Bjørnøya, Svalbard. Polar Res. 14(2). 245251

Salvigsen. O.. Adrielsson, L., Hjort. C.. Kelly. M., Landvik, J. Y. \& Ronnert, L. 1995: Dynamics of the last glaciation of castern Svalbard inferred from glacier-movement indicators. Polar Res. 14(2) . 141-152

Schytt V. . Hoppe G. Blake W. Jr. \& Grosswald M. G. 1968: The extent of the Würm glaciation in the European Arctic. A preliminary seport about the Stockholm University Svalbard Expedition 1966. International Society of Scientific Hydrology. General Assembly in Bern 1967, Publ. no. 207216.

Siegert. M. J. \& Dowdeswell. J. A. 1995: Numerical modelling 
of the Late Weichselian Svalbard-Barents Sea ice sheet. Quat. Res. 43, 1-13.

Solheim, A. \& Kristoffersen, Y. 1984: The physical environment Western Barents Sea, $1: 1,500,000$. Sediments above the upper regional unconformity: thickness, seismic stratigraphy and outline of the glacial history. Norsk Polarinst. $S k r .179 B$. $1-26$.

Sugden, D. E. 1977: Reconstruction of the morphology. dynamics, and thermal characteristics of the Laurentide ice shcet at its maximum. Arct. Alp. Res. 9, 21-47.

Sugden. D. E. 1978: Glacial erosion by the Laurentide ice sheet. J. Glaciol. 20, 367-391.

Svendsen, J. I.. Mangerud, J., Elverhøi, A., Solheim, A. \& Schüttenhelm, R. T. E. 1992: The Late Weichselian glacial maximum on western Spitsbergen inferred from offshore sediment cores. Marine Geology 104, 1-17.
Troitsky, L., Punning, J.-M., Hütt, G. \& Rajamäe. R. 1979: Pleistocene glaciation chronology of Spitsbergen. Boreas 8 , 401-407.

Vorren T. O., Lebesbye E. \& Larsen K. B. 1990: Geometry and genesis of the glacigenic sediments in the southern Barents Sea. Pp. 269-288 in Dowdeswell J. A. \& Scourse J. D. (eds.): Glacimarine environments: Processes and sediments. The Geological Society Special Publication. London.

Wohlfarth, B. Lemdahl, G., Olsson, S. . Persson. T. Snowball. I., Ising, J. \& Jones, V. 1995: Early Holocene environment on Bjørnøya (Svalbard) inferred from multidisiplinary lake sediment studies. Polar Research 14(2), 253-275. 
